\title{
PHYSICAL AND CHEMICAL CHARACTERISTICS OF NEEM OILS EXTRACTED FROM SEED, WHOLE FRUIT AND FLESH
}

\author{
ATTA, NAHED M. M. ${ }^{1}$, GHADA H.H. ISMAIEL ${ }^{2}$, \\ A. S. HASHISH ${ }^{2}$ and ENAAM SH. A. MOHAMED ${ }^{1}$
}
1. Fats and Oils Research Department Food Technology Research Institute (FTRI), (ARC), Giza, Egypt.
2. Special Food and Nutrition Research Department Food Technology Research Institute (FTRI), (ARC), Giza, Egypt.

(Manuscript received 23 April 2015)

\begin{abstract}
$\mathrm{T}$ his work aimed to study the chemical composition of fresh neem seed, whole fruit, and flesh and also their defatted meal. Also this study was carried out to investigate the physical and chemical properties (color, taste, odor, status, RI, FFA, PV, k232, IV, SV and unsap.), fatty acids composition, phenol and flavonoid compounds of neem oils extracted by solvent from seed, whole fruit and flesh. The results can be summarized as follows: Neem seed contained a high percentage of crude oil, protein and crude fiber followed by whole fruit then flesh and vice versa for moisture content. There is difference in oil color extracted from seed, whole fruit and flesh, were greenish-brown, greenishyellow and golden yellow, respectively, while their taste and odor were bitter and unpleasant odor. Values of FFA, k232nm., IV, UNS and SV of neem oil extracted from flesh recorded a higher increased compared to other oils extracted from whole fruit and seed. Analysis of fatty acids by GC-capallary colum of these oils indicated that, high content in oleic acid for fruit and seed oils than that in flesh oil, but alph and gamma linolenic acids in the flesh oil recorded a higher content compared with oils obtained from whole fruit and seed. Results indicated that neem oils extracted from whole fruit and flesh contained high amount of total sterols (82.92 and $76.8 \%$ ), respectively, while neem seed oil contained low amount of $T$. sterols and vice versa in amount of total hydrocarbons of these previous oils. Analysis of phenol and flavonoids compounds by HPLC of neem oils from whole fruit, seed and flesh reveal that it contained 22 and 11 phenolic and flavonoid compounds, respectively. Also analysis reveals neem fruit of oil contained a higher amount from all phenols compounds followed by flesh oil then seed oil. Also pyrogallol compound recorded a higher concentration compared to others phenol compounds in all neem oils under study.

Keywords: Neem seed, fruit and flesh oils, physical and chemical characteristics, unsaponifiable matter, fatty acid composition, phenol and flavonoid compounds of oils.
\end{abstract}

\section{INTRODUCTION}

Neem is an omnipotent tree and a sacred gift of nature. Neem tree is mainly cultivated in the Indian subcontinent. Neem is a member of the mahogany family, 
Meliaceae. Today, it is known by the botanice name Azadirachtaindica ( $A$. indica ) A. Juss. Neem has been used extensively by humankind to treated various ailments before the availability of written records which recorded the beginning of history. (Venugopalan and Visweswaran. 2013).

Azadirachtaindica A. Juss (Meliaceae ), well known as the neem tree, is widely distributed in the tropical zones of Africa, south Asia and India. A. indica has been used as a traditional medicine for more than 2000 years in India, because of its valuable biological activities (anti- inflammatory, anti- ulcer, anti- malarial, antibacterial and anti- oxidant activities. (shin-ichiro et al., 2014).

In the recent period, it was planted nearly 4,000neem tress in Egypt found in the Delta zone and South Sinai Governorate (Wikipedia,2014). The adult of neem tree produces about $350 \mathrm{~kg}$ of fruits and this amount is given about $30 \mathrm{~kg}$ of seeds. (Information unit-Central Administration for Agricultural Extension, 2015).

The neem oil yield that can be obtained from neem seed kernels also varies widely in literature from $25 \%$ to $45 \%$. The oil can be obtained through pressing of the seed kernel. Neem oil can also be obtained by solvent extraction from seed, fruit and kernel (Wikipedia, 2014).

Seed of Azadirachtaindica, popularly known as neem, has $45 \%$ oil and is a minor of oil seed of considerable potential. Neem oil is usually bitter and non. edible. The oil contains $50 \%$ oleic and $15 \%$ linoleic and no usual fatty acids. The physic-chemical parameters are within the range of other edible oils. (Rukmimi,1987).

Neem kernels contain $30-50 \%$ of oil and many active ingredients ( limonoids, mono-, di-sesqui-, and triterpenoids, coumarins, chromones, lignins, flavonoids and other phenols) having antifeedant, growth inhibiting, anti-oviposition and insecticidal activities. (Schmutterer, 1995).

Neem oil fatty acids comprise oleic, stearic, palmitic and linoleic acids. The fatty acids composition of the neem oil may vary from tree to tree because of genetic make-up, (Faye, 2010).

The predominant fatty acids in A. indica seed oil were oleic (43.5\%), linoleic (18.7\%), palmitic (17.8\%) and stearic (17.9\%) acids (Djenontinet al., 2012 and Gosse et al., 2005).

Djenontin et al., 2012 found differences in sterol composition of neem oils from Ivory coast and India. The major sterol is $\beta$-sitosterol $(7.77 \mathrm{mg} / 100 \mathrm{~g})$ in neem seed oil, also it contains $1.2 \%$ total unsaponifiable matter, $30.8,62.3$ and $6.9 \mathrm{ppm}$ for $\alpha, \gamma$ and $\sigma$ tocopherols respectively, while $\beta$ - tocopherol not detected. 
Protein and ash contents in neem seed cake were 31.4 and $5.3 \%$, respectively (Djenontin et al., 2012).

This study demonstrates the differences between physicochemical properties, fatty acids composition, total tocopherols, soluble fat vitamins, phenol and flavonoid compounds and unsaponifiable matters of neem oils extracted from neem seed, whole fruit and flesh.

\section{MATERIALS AND METHODS}

\section{Materials:}

Neem fruit : were obtained from Al-Kanater experimental station, Horticultural Research Institute, Agricultural Research Center, El-Giza Governorate, Egypt. The fruits were harvested from trees in season 2014.

Neem seed and flesh: The seeds were manually separated from neem fruit, then cleaned from any adhering flesh furthermore the decorticated flesh from fruit collected alone and cleaned.

All chemicals :were come from Sigma Chemical Co. (St. Louis, MO, USA). The stock standard solutions were prepared by dissolving the standard phenolic compounds and flavonoids in the appropriate volume of $50 \%$ aqueous methanol to produce a final concentration of $1 \mathrm{mg} / \mathrm{ml}$. Stock from standards solutions were stored in the dark at $18^{\circ} \mathrm{C}$.

\section{Methods:}

\section{1- Extraction of oil from neem seed, whole fruit and flesh:}

Neem seed, fruit and flesh were dried at $40^{\circ} \mathrm{C}$ overnight in oven. The dried seed, fruit and flesh were ground using grinder model (MFIO micro fine grinder drive), soaked in pure $\mathrm{n}$ - hexan for $24 \mathrm{~h}$. The miscella were collected and filtered. This process was repeated three times using fresh solvent each time. The solvent was evaporated under vacuum in rotary evaporator at $40^{\circ} \mathrm{C}$, the moisture in oil was removed over anhydrous sodium sulfate, filtered (whatman No 1 ) and stored in brown bottles and then kept at $5^{\circ} \mathrm{C}$ until analysis A.O.C.S.(1981).

2- Chemical composition of fresh neem seed, whole fruit and flesh and their deffated meals:

- Moisture, crude oil, protein, crude fiber and ash contents were determined according to the methods of A.O.A.C. (2000).

- Total carbohydrates were estimated by deference.

3- Physical and chemical characteriestics of neem seed, whole fruit and flesh oils:

- Color, taste, odor and status of neem oils were carried out by ten volunteered staff members at Food Technology Research Institute whom are working in the field of food science and technology for several years. 
- Refractive index (RI) : RI of neem oils was determined at $25{ }^{\circ} \mathrm{C}$ according to A.O.A.C. (2000) by using refractometer (NXRL-3 poland).

- Free fatty acids (FFA) and peroxide value (Meq. $\mathrm{O}_{2} / \mathrm{kg}$ oil) were determined according to the methods of the A.O.A.C. (1995).

- Iodine and saponification values of neem oils were calculated from fatty acids percentage by equation according to Susana Nelson (1995).

- Absorbency in ultravioletat 232 and $270 \mathrm{~nm}$. :

Ultraviolet and visible spectra were conducted using a pye unicum double beam recording spectrophotometer Model SP 1600, as described by Kates (1972). The oil samples were dissolved in freshly distilled cyclohexane and the absorption were measured at 232 and $270 \mathrm{~nm}$.

\section{4- Fatty acids composition:}

The fatty acids methyl esters were prepared using trans- esterification with cold methanolic solution of potassium hydroxide. The fatty acids methyl esters were identified by GC- capillary column according to the methods of IOOC (2001).

\section{5- Identification of unsaponifiable matter by GC:}

The unsaponifiable matter was separated from the oils at room temperature according to the method of A.O.A.C. (2000). Identification of hydrocarbons and sterols content of the unsaponifiable matter was carried out.

6- Determination of bioactive in crude neem seed, whole fruit and flesh oils :

- Determination of total tocopherols:

The total tocopherols and was determined according to the methods of Wong et al., (1988).

- Determination of vitamins ( $A, D$ and $K)$ :

Vitamins $A, D$ and $K$ were determined according to the methods of Perez-Ruiz et al.,(2007), Nöll (1996) and Wittiy et al., (2013), respectively.

7- Identification of phenolic and flavonoid compounds :

Phenolic and flavonoid compounds were identified by HPLC according to the methods of Goupyet al., (1999).

8- Statistical analysis:The obtained data were exposed analysis of variance. Duncan's Multiple range tests at $(p \leq 0.05)$ level was used to compare between means. The analysis was carried out using the PRO-ANOVA procedure of Statistical Analysis System (SAS, 1996).

\section{RESULTS AND DISCUSSION}

\section{1-Chemical composition of fresh neem :}

Table (1) shows the percentage of moisture, protein, crude fat, fiber, ash and total carbohydrates in fresh neem seed, whole fruit and flesh. There are a significant 
differences between the concentration of these contents. The highest percentages of the protein, crude oil and fiber belong to neem seed and the lowest concentration belong to neem flesh and vice versa in moisture content. With regarding the tabulated data in Table (2), total carbohydrates and ash contents of defatted meal of flesh recorded a higher increament compared to them in defatted meal of seed and fruit. On the other hand, the highest content of protein and crude fiber was found in neem seed meal compared with whole fruit and flesh meal.

Table 1. Chemical composition of fresh neem (\%) :

\begin{tabular}{|c|c|c|c|c|c|c|}
\hline Samples & Moisture & Protein & Crude oil & Crude fiber & Ash & *Carbohydrate \\
\hline Seed & $57.89^{\mathrm{C}}$ & $4.35^{\mathrm{A}}$ & $19.85^{\mathrm{A}}$ & $7.26^{\mathrm{A}}$ & $1.61^{\mathrm{C}}$ & $9.04^{\mathrm{C}}$ \\
\hline Whole fruit & $63.93^{\mathrm{B}}$ & $1.6^{\mathrm{C}}$ & $13.26^{\mathrm{B}}$ & $4.5^{\mathrm{B}}$ & $1.63^{\mathrm{A}}$ & $15.08^{\mathrm{A}}$ \\
\hline Flesh & $72.87^{\mathrm{A}}$ & $1.33^{\mathrm{C}}$ & $10.03^{\mathrm{C}}$ & $1.85^{\mathrm{C}}$ & $1.52^{\mathrm{B}}$ & $12.4^{\mathrm{B}}$ \\
\hline
\end{tabular}

* Calculated by deference Data are mean $(n=3, P<0.05)$. Means with the same letter are not significantly different

Table 2. Chemical composition of defatted neem meals (\%) :

\begin{tabular}{|c|c|c|c|c|}
\hline Item & Protein & Crude fiber & Ash & $*$ \\
& & & & \\
\hline Seed & $17.93^{\mathrm{A}}$ & $29.92^{\mathrm{A}}$ & $6.62^{\mathrm{C}}$ & $45.53^{\mathrm{C}}$ \\
\hline Whole fruit & $7.05^{\mathrm{C}}$ & $19.81^{\mathrm{B}}$ & $7.18^{\mathrm{B}}$ & $65.96^{\mathrm{B}}$ \\
\hline Flesh & $7.97^{\mathrm{B}}$ & $10.82^{\mathrm{C}}$ & $8.89^{\mathrm{A}}$ & $72.32^{\mathrm{A}}$ \\
\hline
\end{tabular}

*Calculated by deference Data are mean $(n=3, P<0.05)$. Means with the same letter are not significantly different

\section{2 -Physical and chemical characteristics of crude neem oils:}

Table (3) gives the physical and chemical properties of neem oils. From the results presented in Table (3), it could be observed that the neem oils extracted from seed, whole fruit and flesh varies in color, were greenish- brown, greenish- yellow and golden-yellow, respectively, while all neem oils were bitter and unpleasant odor. The bitter taste of neem oils may be due to the content of many triterpenoid compound. Also the unpleasant odor is due to presence of nimbidinic acid, which contains sulphur (Rukmini, 1987). The status of oils at room temperature was liquid for oils from seed and whole fruit but it was solid for oil extracted from flesh, this may be due to phospholipids inside found unsaponifiable matter (13.46\%) of flesh oil. Regarding to data in the same table it could be noticed that the refractive index (RI at $25^{\circ} \mathrm{C}$ ) of neem oils extracted from neem seed and whole fruit recorded 1.4760 and 1.4770 , respectively while it was not detected in oil obtained from neem flesh. Also data in the same table, shown that the values of FFA, UV. absorbance at $232 \mathrm{~nm} .(\mathrm{K} 232 \mathrm{~nm}$.) and iodine value (IV) of neem oil extracted from flesh recorded the highest values as compared to neem oils extracted from seed and fruit. This increase in the FFA and 
$\mathrm{K} 232 \mathrm{~nm}$. may be due to the degradation and hydrolysis of oil by increasing the moisture content in flesh $(72.87 \%)$ which caused increase in the previous parameters compared with that in the seed and fruit ( 57.89 and $63.93 \%$ ). Also, the increase in IV of oil extracted from flesh may be due to it contains a higher amount of poly unsaturated fatty acid (C18: 3n3, 12.3\%) compared with oils extracted from seed and fruit ( 0.99 and $1.09 \%$, respectively). From the same table it could be noticed that the highest saponification value (SV) and unsaponifiable matter \% (UNS) was found for flesh oil (202.97 and 13.46\%) compared with seed and fruit oils (196.96 and 2.89\%), (196.69 and $5.45 \%)$ respectively.

On the other hand, the highest values of (PV) and K270 nm. Were found for seed oil followed by whole fruit and flesh oil. This increase in PV and K270nm. may be due to oxidative degradation in oils from seed and fruit compared with flesh oil. Genrally the physical and chemical properties are within the range of other vegetable oils. This results coincide with that mentioned by Rukmimi (1987).

Table 3. Physical and chemical characteriestics of crude neem oils:

\begin{tabular}{|c|c|c|c|}
\hline \multirow{2}{*}{ Item } & \multicolumn{3}{|c|}{ Crude neem oils extracted from } \\
\cline { 2 - 4 } & Seed & Whole fruit & Flesh \\
\hline Color & Greenish-brown & Greenish-yellow & Golden-yellow \\
\hline Taste & Bitter & Bitter & Bitter \\
\hline Odor & $\begin{array}{c}\text { Combine the odors } \\
\text { of peanet and } \\
\text { garlic }\end{array}$ & $\begin{array}{c}\text { Combine the odors } \\
\text { of peanet and } \\
\text { garlic }\end{array}$ & $\begin{array}{c}\text { Combine the odors } \\
\text { of peanet and } \\
\text { garlic }\end{array}$ \\
\hline Status & Liquid & Liquid & Soild \\
\hline Refractive index (RI at $25^{\circ} \mathrm{C}$ ) & $1.4760^{\mathrm{A}}$ & $1.4770^{\mathrm{A}}$ & Nd \\
\hline Free fatty acid \% & $1.44^{\mathrm{B}}$ & $1.42^{\mathrm{B}}$ & $5.27^{\mathrm{A}}$ \\
\hline Peroxide value (Meq. $\mathrm{O}_{2} / \mathrm{kg}$ oil) & $15.29^{\mathrm{A}}$ & $11.33^{\mathrm{AB}}$ & $9.18^{\mathrm{B}}$ \\
\hline Conjugated diene at $232 \mathrm{~nm}$. & $25.53^{\mathrm{B}}$ & $28.2^{\mathrm{AB}}$ & $28.78^{\mathrm{A}}$ \\
\hline Conjugatedtriene at $270 \mathrm{~nm}$. & $4.58^{\mathrm{A}}$ & $3.27^{\mathrm{B}}$ & $3.16^{\mathrm{B}}$ \\
\hline Iodine value (I2/100g oil) & $75.52^{\mathrm{B}}$ & $74.98^{\mathrm{B}}$ & $91.75^{\mathrm{A}}$ \\
\hline Saponification value (mg KOH/g oil) & $196.96^{\mathrm{B}}$ & $196.69^{\mathrm{B}}$ & $202.97^{\mathrm{A}}$ \\
\hline Unsaponifiable matter (unsap)\% & $2.89^{\mathrm{C}}$ & $5.45^{\mathrm{B}}$ & $13.46^{\mathrm{A}}$ \\
\hline
\end{tabular}

Data are mean $(n=3, P<0.05)$. Means with the same letter are not significantly different $\mathrm{Nd}$. means not determined

\section{3-Fatty acids composition of crude neem oils:}

Separation and determination of fatty acids methyl esters were carried out by GCCapillary column chromatography to identify their types and amounts. From the results in Table (4), it could be noticed that, the predominant saturated fatty acids of extracted oil from neem flesh was palmitic acid (19.17\%), while stearic acid was major in oils from seed and whole fruit (15.86 and $17.5 \%$, respectively). Also the major unsaturated fatty acid was oleic acid in seed, fruit and flesh oil (43.6,45.3 and $30.6 \%$,respectively), followed by linoleic acid (18.95, 18.34 and 16.25\%, respectively). The highest $\alpha$-linolenic and $\gamma$ - linoleneic acids were found in flesh oil 
( $12.31 \%$ and $1.51 \%$, respectively). On the other hand, the percentages of total saturated fatty acid of neem seed, whole fruit and flesh oils, were 32.07,32.26 and $34.86 \%$ and total unsaturated fatty acids were 65.94,65.88 and $64.22 \%$, respectively. Generally, there is no significant differences in the percentage of total saturated fatty acid of seed and whole fruit oils (32.07 and $32.26 \%$, respectively), meanwhile the highest TSFA was found in flesh oil (34.86\%). Concerning TUNSFA there is no significant differences between seed and whole fruit oils $(65.94,65.88 \%$ respectively), meanwhile the lowest TUSFA was observed in flesh oil (64.22\%). These results are in agreement with those obtained by Djenontin et al., (2012) and Gosse et al., (2005). Finally neem seed, whole fruit and flesh oils contained a high amount of

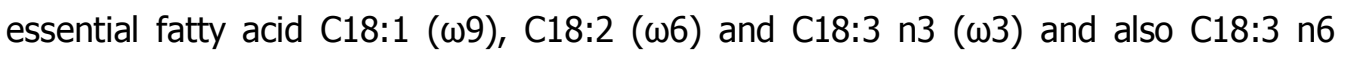
(Gamma linolenic acid), which increased the nutritional properties of investigated oils after some treatments (debitterization, refining, bleaching and deodorization process). Generally, these fatty acids composition of neem seed and whole fruit oil are close to finding by Djenontin et al., (2012) and Faye (2010). But there are no reference literature data about fatty acids composition of neem flesh oil.

Table 4. Fatty acids composition of crude neem oils (\%)

\begin{tabular}{|c|c|c|c|}
\hline \multirow[b]{2}{*}{ Fatty acids } & \multicolumn{3}{|c|}{ Crude neem oil extracted from } \\
\hline & Seed & Whole fruit & Flesh \\
\hline Myristic acidC14:0 & $0.41^{\mathrm{B}}$ & $0.12^{\mathrm{B}}$ & $2.34^{\mathrm{A}}$ \\
\hline Palmitic acid $\mathrm{C} 16: 0$ & $11.25^{\mathrm{B}}$ & $11.56^{\mathrm{B}}$ & $19.17^{\mathrm{A}}$ \\
\hline Palmitoleic acidC16:1( $\omega 7)$ & $0.88^{\mathrm{AB}}$ & $0.50^{\mathrm{B}}$ & $1.28^{\mathrm{A}}$ \\
\hline Margarinic acid C17:0 & $0.23^{\mathrm{B}}$ & $0.29^{B}$ & $1.87^{\mathrm{A}}$ \\
\hline Heptadecenoic acid C17:1 & $0.17^{B}$ & $0.17^{\mathrm{B}}$ & $1.05^{\mathrm{A}}$ \\
\hline Stearic acid C18:0 & $15.86^{\mathrm{B}}$ & $17.5^{\mathrm{A}}$ & $9.7^{C}$ \\
\hline Oleic acid C18:1( $\omega 9)$ & $43.6^{\mathrm{A}}$ & $45.3^{\mathrm{A}}$ & $30.6^{\mathrm{B}}$ \\
\hline Linoleic acid C18:2 $(\omega 6)$ & $18.95^{\mathrm{A}}$ & $18.34^{\mathrm{B}}$ & $16.25^{\mathrm{C}}$ \\
\hline$\gamma$ - linolenic acid C18:3n6 ( $\omega 6)$ & $0.95^{\mathrm{B}}$ & $0.48^{\mathrm{C}}$ & $1.51^{\mathrm{A}}$ \\
\hline$\alpha-$ linolenic acid $\mathrm{C} 18: 3 \mathrm{n} 3(\omega 3)$ & $0.99^{\mathrm{B}}$ & $1.09^{B}$ & $12.3^{\mathrm{A}}$ \\
\hline Arachidic acid C20:0 & $3.89^{\mathrm{A}}$ & $2.59^{\mathrm{A}}$ & $1.58^{\mathrm{A}}$ \\
\hline Eicosenoic acid C20:1 ( $\omega 9)$ & $0.399^{B}$ & -- & $1.23^{\mathrm{A}}$ \\
\hline Unknown & $1.031^{\mathrm{A}}$ & $0.66^{\mathrm{B}}$ & -- \\
\hline Behenic acid C22:0 & $0.26^{\mathrm{A}}$ & $0.3^{\mathrm{A}}$ & $0.199^{A}$ \\
\hline Unknown & $0.96^{\mathrm{A}}$ & $1.2^{\mathrm{B}}$ & $0.921^{\mathrm{A}}$ \\
\hline Ligoceric acid C24:0 & $0.163^{\mathrm{A}}$ & $0.2^{\mathrm{A}}$ & -- \\
\hline TSFA. & $32.07^{B}$ & $32.26^{\mathrm{B}}$ & $34.86^{A}$ \\
\hline TUNSFA. & $65.94^{\mathrm{A}}$ & $65.88^{A}$ & $64.22^{\mathrm{B}}$ \\
\hline TSFA./TUNSFA. & $0.48^{\mathrm{B}}$ & $0.49^{B}$ & $0.54^{\mathrm{A}}$ \\
\hline
\end{tabular}

Data are mean $(n=3, P<0.05)$. Means with the same letter are not significantly different

\section{4 -The relative percentages of unsaponifiable matter components of crude neem oils:}

Unsaponifiable matters of neem seed, whole fruit and flesh oils were fractionated by GC technique and the obtained results are shown in Table (5). From the results 
presented in Table (5) it could be observed that $\mathrm{C}_{21}(31.07 \%)$ was the major hydrocarbon followed by $\mathrm{C}_{20}(22.32 \%)$ in neem seed oil, while it were ( 3.98 and $1.7 \%)$ and (5.61 and $0.82 \%)$ in neem fruit and flesh oils, respectively. Also $C_{21}$ considerable the major hydrocarbon for the neem oil extracted from flesh. As the sterols $\beta$-sitosterol was the main sterols in neem seed and whole fruit, which it was 11.56 and $16.24 \%$, respectively, but it showed decrease in flesh oil $(8.51 \%)$, while campesteral was the major sterols in neem oils extracted from flesh (24.72\%) followed by whole fruit oil (16.2\%), while it was recorded a higher decrease in neem seed oil (1.92\%). On the other hand, campestenol recorded the highest value in flesh oil followed by whole fruit and seed oil. And also from these data it could be stated that the amount of total sterols of whole fruit oil was the highest amount (82.92\%) followed by oils from flesh $(76.80 \%)$ then seed oil (36.78\%). Finally, these sterol composition of all neem oils under study are close to sterol of neem seed oil reported by Djenontinet al., (2012), Faye (2010)and Gosse et al., (2005).

Table 5. Identification of unsaponifiable matter of crude neem oils (\%)

\begin{tabular}{|c|c|c|c|}
\hline \multirow{2}{*}{$\begin{array}{l}\text { Unsaponifiable matter \% } \\
\text { Components }\end{array}$} & \multicolumn{3}{|c|}{ Crude neem oils extracted from } \\
\hline & Seed & Whole fruit & Flesh \\
\hline \multicolumn{4}{|l|}{ Hydrocarbons: } \\
\hline C16 & 0.24 & --- & --- \\
\hline $\mathrm{C} 17$ & 0.29 & --- & --- \\
\hline $\mathrm{C} 18$ & $0.47^{\mathrm{A}}$ & $0.27^{C}$ & $0.43^{\mathrm{B}}$ \\
\hline C19 & $0.59^{A}$ & $0.44^{\mathrm{B}}$ & $0.6^{\mathrm{A}}$ \\
\hline $\mathrm{C} 20$ & $22.32^{\mathrm{A}}$ & $1.7^{\mathrm{B}}$ & $0.82^{\mathrm{C}}$ \\
\hline $\mathrm{C} 21$ & $31.07^{\mathrm{A}}$ & $3.48^{\mathrm{C}}$ & $5.61^{\mathrm{B}}$ \\
\hline $\mathrm{C} 22$ & $3.52^{\mathrm{A}}$ & $1.66^{\mathrm{B}}$ & $0.68^{\mathrm{C}}$ \\
\hline $\mathrm{C} 23$ & $0.57^{B}$ & $0.54^{C}$ & $0.60^{\mathrm{A}}$ \\
\hline C24 & $0.79^{C}$ & $3.71^{\mathrm{A}}$ & $4.07^{\mathrm{A}}$ \\
\hline $\mathrm{C} 25$ & $2.02^{C}$ & $2.88^{\mathrm{A}}$ & $2.47^{\mathrm{B}}$ \\
\hline Squalene & $0.29^{C}$ & $0.61^{\mathrm{B}}$ & $0.7^{\mathrm{A}}$ \\
\hline $\mathrm{C} 28$ & $1.05^{c}$ & $1.79^{\mathrm{A}}$ & $1.22^{\mathrm{B}}$ \\
\hline \multicolumn{4}{|l|}{ Sterols: } \\
\hline$\beta$ - Estradiol & $2.81^{\mathrm{B}}$ & $3.31^{\mathrm{A}}$ & $0.88^{\mathrm{C}}$ \\
\hline Unknown & $2.84^{\mathrm{C}}$ & $9.54^{\mathrm{B}}$ & $11.91^{\mathrm{A}}$ \\
\hline Cholesterol & $3.72^{\mathrm{A}}$ & $1.31^{B}$ & --- \\
\hline Brassicasterol & $2.97^{A}$ & $0.89^{\mathrm{B}}$ & --- \\
\hline Campesterol & $1.92^{\mathrm{C}}$ & $16.2^{\mathrm{B}}$ & $24.72^{\mathrm{A}}$ \\
\hline Campestenol & $3.99^{C}$ & $9.14^{\mathrm{B}}$ & $10.59^{A}$ \\
\hline Unknown & ---- & $10.01^{\mathrm{A}}$ & $5.04^{B}$ \\
\hline Stigmasterol & $1.63^{\mathrm{B}}$ & $2.43^{\mathrm{A}}$ & $1.4^{\mathrm{C}}$ \\
\hline$\beta$ - Sitosterol & $11.56^{\mathrm{B}}$ & $16.24^{\mathrm{A}}$ & $8.51^{\mathrm{C}}$ \\
\hline Sitostanol & $3.1^{\mathrm{B}}$ & $5.67^{A}$ & $2.09^{C}$ \\
\hline$\Delta 5$-avenasterol & $2.24^{c}$ & $5.31^{\mathrm{A}}$ & $3.98^{\mathrm{B}}$ \\
\hline$\Delta 5,24$ stigmasterial & --- & $3.02^{\mathrm{A}}$ & $2.89^{B}$ \\
\hline Gramisterol & --- & --- & 2.12 \\
\hline$\Delta 7$-avenasterol & --- & --- & 2.67 \\
\hline T.Hydrocarbons & $63.22^{\mathrm{A}}$ & $17.08^{\mathrm{C}}$ & $23.2^{\mathrm{B}}$ \\
\hline T.Sterols & $36.78^{C}$ & $82.92^{\mathrm{A}}$ & $76.80^{\mathrm{B}}$ \\
\hline
\end{tabular}

Data are mean $(n=3, P<0.05)$. Means with the same letter are not significantly different 


\section{5-Fat soluble vitamins in crude neem oils:}

From the data in Table (6) it could be noticed that, vitamin $\mathrm{K}$ recorded the highest content compared with other vitamins in all oils from seed, whole fruit and flesh. On the other hand, there is a higher difference in a mount of tocopherol of neem oils extracted from seed, whole fruit and flesh by the way concentration of total tocopherols in neem oil of whole fruit $(82.6 \mathrm{ppm})$ was higher than that of oils from seed and flesh (48.1 and 34.5 ppm), respectively. This finding are agreement with previously published results by Djenontin et al., (2012).

Table 6.The content of fat soluble vitamins in crude neem oils ( $\mathrm{ppm})$.

\begin{tabular}{|l|l|c|c|}
\hline \multirow{2}{*}{ Vitamins } & \multicolumn{3}{|c|}{ Crude neem oil extracted from } \\
\cline { 2 - 4 } & Seed & Whole fruit & Flesh \\
\hline Vitamin A & $15.7^{\mathrm{B}}$ & $26.9^{\mathrm{A}}$ & $13.2^{\mathrm{C}}$ \\
\hline Vitamin D & $9.85^{\mathrm{A}}$ & $6.83^{\mathrm{B}}$ & $3.02^{\mathrm{C}}$ \\
\hline Vitamin K & $721^{\mathrm{A}}$ & $344.3^{\mathrm{C}}$ & $376.3^{\mathrm{B}}$ \\
\hline Total tocopherol & $48.1^{\mathrm{B}}$ & $82.6^{\mathrm{A}}$ & $34.5^{\mathrm{C}}$ \\
\hline
\end{tabular}

Data are mean $(n=3, P<0.05)$. Means with the same letter are not significantly different

\section{6-Phenolic compounds in crude neem oils:}

Table (7) shows the amount of phenolic compounds in crude neem oils extracted from seed, whole fruit and flesh. From the results in this table it could be observed that, the phenolic compounds in all previous samples of oil found to be twenty two compounds (gallic, pyrogallol, 3- hydroxytyrosol, protocatchoic, chlorogenic, catechol, catechin, caffeine, $\mathrm{P}-\mathrm{OH}$ benzoic, vanillic, ferulic, iso-ferulic, stolleuropein, reversetrol, E- vanillic, ellagic, alpha- coumaric, salycillic, 3,4,5 methoxycinnamic, coumarin, pcoumaric and cinnamic). Also from the results, there is a significant difference between the concentration of all previous phenolic compounds in neem oils extracted from whole fruit, seed and flesh, the lowest content of all phenolic compounds presence in neem seed oil and the highest amount belong to whole fruit oil, but flesh oil contains intermediate amount from these compounds. On the other hand, pyrogallol compound recorded the highest content in all the previous samples of crude neem oil compared to the other phenolic compounds, while cinnamic compound recorded the lowest amount in all oils. 
Table 7. The content of phenolic compounds found in crude neem oils $(\mathrm{mg} / 100 \mathrm{~g})$.

\begin{tabular}{|c|c|c|c|}
\hline \multirow{2}{*}{$\begin{array}{c}\text { Phenolic } \\
\text { compounds }\end{array}$} & \multicolumn{3}{|c|}{$\begin{array}{c}\text { Phenolic compounds content of neem oils } \\
\text { extracted from }\end{array}$} \\
\cline { 2 - 4 } & Seed & Whole fruit & Flesh \\
\hline Gallic & $0.85^{\mathrm{C}}$ & $3.71^{\mathrm{A}}$ & $2.86^{\mathrm{B}}$ \\
\hline Pyrogallol & $58.1^{\mathrm{C}}$ & $172.7^{\mathrm{A}}$ & $114.6^{\mathrm{B}}$ \\
\hline 3- hydroxvtyrosol & $1.21^{\mathrm{C}}$ & $26.3^{\mathrm{A}}$ & $25.09^{\mathrm{B}}$ \\
\hline Protocatchoic & $1.11^{\mathrm{C}}$ & $5.74^{\mathrm{A}}$ & $13.63^{\mathrm{B}}$ \\
\hline Chlorogenic & $1.07^{\mathrm{C}}$ & $14.05^{\mathrm{A}}$ & $14.08^{\mathrm{B}}$ \\
\hline Catechol & $2.16^{\mathrm{C}}$ & $16.08^{\mathrm{A}}$ & $22.53^{\mathrm{B}}$ \\
\hline Catechin & $0.57^{\mathrm{C}}$ & $23.1^{\mathrm{A}}$ & $3.15^{\mathrm{B}}$ \\
\hline Caffeine & $0.083^{\mathrm{C}}$ & $3.85^{\mathrm{A}}$ & $5.05^{\mathrm{B}}$ \\
\hline P- OH benzoic & $1.09^{\mathrm{C}}$ & $6.15^{\mathrm{A}}$ & $7.70^{\mathrm{C}}$ \\
\hline Vanillic & $6.71^{\mathrm{B}}$ & $7.41^{\mathrm{A}}$ & $4.4^{\mathrm{B}}$ \\
\hline Ferulic & $1.24^{\mathrm{C}}$ & $8.33^{\mathrm{A}}$ & $17.3^{\mathrm{B}}$ \\
\hline Iso-ferulic & $0.35^{\mathrm{C}}$ & $4.79^{\mathrm{A}}$ & $2.2^{\mathrm{B}}$ \\
\hline Stolleuropein & $11.42^{\mathrm{C}}$ & $28.68^{\mathrm{A}}$ & $54.13^{\mathrm{B}}$ \\
\hline Reversetrol & $1.71^{\mathrm{C}}$ & $5.15^{\mathrm{A}}$ & $8.1^{\mathrm{B}}$ \\
\hline E- vanillic & $3.82^{\mathrm{C}}$ & $58.13^{\mathrm{A}}$ & $3.3^{\mathrm{B}}$ \\
\hline Ellagic & $0.91^{\mathrm{C}}$ & $9.1^{\mathrm{A}}$ & $11.5^{\mathrm{B}}$ \\
\hline Alpha- coumaric & $0.23^{\mathrm{C}}$ & $3.54^{\mathrm{A}}$ & $2.82^{\mathrm{C}}$ \\
\hline Salycillic & $2.13^{\mathrm{C}}$ & $13.62^{\mathrm{A}}$ & $6.2^{\mathrm{B}}$ \\
\hline $3,4,5$ Methoxycinnamic & $4.96^{\mathrm{B}}$ & $7.78^{\mathrm{A}}$ & $4.5^{\mathrm{C}}$ \\
\hline Coumarin & $0.38^{\mathrm{C}}$ & $6.63^{\mathrm{A}}$ & $1.38^{\mathrm{B}}$ \\
\hline p- Coumaric & $2.24^{\mathrm{C}}$ & $6.66^{\mathrm{A}}$ & $2.06^{\mathrm{A}}$ \\
\hline Cinnamic & $0.68^{\mathrm{C}}$ & & \\
\hline & & & \\
\hline
\end{tabular}

Data are mean $(n=3, P<0.05)$. Means with the same letter are not significantly different

\section{7-Flavonoid compounds in crude neem oils:}

From the data found in Table (8), it could be concluded that, neem oils produced from seed, whole fruit and flesh contained eleven flavonoid compounds (naringin, rutin, hesperidin, rosmarinic, quercetrin, quercetin, naringinin, kaempferal, hespertin, apegenin and 7- hydroxyl-flavone). Also, it is clear from the data presented in this table, that there is a significant difference between the amount of the flavonoids in all previous crude neem oils, the highest amount of all these flavonoids is related to neem whole fruit oil, followed by flesh oil then neem seed oil. Commonlly, there no reference literature data about vitamins, phenolic and flavonoid compounds.

Table 8. The content of flavonoid compounds found in crude neem oils $(\mathrm{mg} / 100 \mathrm{~g})$.

\begin{tabular}{|c|c|c|c|}
\hline \multirow{2}{*}{ Flavonoids } & \multicolumn{3}{|c|}{ Flavonoid compounds content of neem oils extracted from } \\
\cline { 2 - 4 } & Seed & Whole fruit & Flesh \\
\hline Naringin & $2.13^{\mathrm{A}}$ & $2.21^{\mathrm{A}}$ & $0.08^{\mathrm{B}}$ \\
\hline Rutin & $0.59^{\mathrm{C}}$ & $2.09^{\mathrm{A}}$ & $1.50^{\mathrm{B}}$ \\
\hline Hesperidin & $0.61^{\mathrm{C}}$ & $1.57^{\mathrm{A}}$ & $0.96^{\mathrm{B}}$ \\
\hline Rosmarinic & $0.13^{\mathrm{C}}$ & $1.36^{\mathrm{A}}$ & $2.23^{\mathrm{B}}$ \\
\hline Quercetrin & $0.99^{\mathrm{C}}$ & $3.24^{\mathrm{A}}$ & $1.2^{\mathrm{B}}$ \\
\hline Quercetin & $0.27^{\mathrm{C}}$ & $1.46^{\mathrm{A}}$ & $1.63^{\mathrm{B}}$ \\
\hline Naringinin & $0.23^{\mathrm{C}}$ & $1.86^{\mathrm{A}}$ & $1.6^{\mathrm{B}}$ \\
\hline Kaempferal & $0.74^{\mathrm{C}}$ & $2.31^{\mathrm{A}}$ & $1.5^{\mathrm{B}}$ \\
\hline Hespertin & $1.39^{\mathrm{B}}$ & $2.94^{\mathrm{A}}$ & $1.27^{\mathrm{B}}$ \\
\hline Apegenin & $0.11^{\mathrm{C}}$ & $1.38^{\mathrm{A}}$ & $1.40^{\mathrm{A}}$ \\
\hline 7- Hydroxyl-flavone & $0.08^{\mathrm{B}}$ & $1.45^{\mathrm{A}}$ & \\
\hline
\end{tabular}

Data are mean $(n=3, P<0.05)$. Means with the same letter are not significantly different 


\section{CONCLUSION}

The aforementioned results declared that the seed, whole fruit and flesh are a good source of oil and high content of natural antioxidants (phenolic and flavonoid compounds and unsaponifiable matter) to rise the efficiency of oxidative stability in some oils (poor oxidative stability) and also their meals are rich in protein and carbohydrates content, whilst the odor and bitter taste of these oils are undesirable that further studied should be carried out on the debitterization, refining, bleaching and deodorization and their effects on neem oil quality .

\section{REFERENCES}

1. A.O.A.C. 2000. Official Methods of Analysis of the Association of the Analytical Chemistspublished by the A.O.A.C international 17th edition, Washington D.C. USA.

2. A.O.A.C. 1995. Official Methods of Analysis of the Association of the Analytical Chemists published by the A.O.A.C international 16th edition, Washington D.C. USA.

3. A.O.C.S. 1981. Official and tentative methods of analysis published by American Oil Chemists Society. $2^{\text {nd }}$ Ed.chicagolllionois,USA.

4. Djenontin,T.S., Valentin, D.W., Felicien, A., Paul, I. Dominique, K.C.S. and Daniel, P. 2012. Composition of Azadirachtaindica and corapaprocera (Meliaceae) seed oils and cakes obtained after oil extraction. Industrial Crops and Products, 38,3949.

5. Faye, M., 2010. Nouveau procede de fractionnement de la graine de neem (Azadirachtaindica.A.Juss) senegalais production d'un bio-pesticide d'huile el de tourteau. PhD.These. University of Toulouse,2G7p.

6. Gosse, B., Amissa, A. A., Adje, F. N. and Niamake, F.B. 2005. Analysis of components of neem (Azadirachtaindica) oil by diverse chromatographic techniques.J. liq.Chrom.Rol.Technol. 28, 2225-2233.

7. Goupy, P., Hugues, M., Biouin, P. and Amiot, M. J. 1999. Antioxidant composition and activity of barley (Hordeumvulgare) and malt extracts and isolated phenolic compounds. J. Sci. Food Agric. 79: 16250-16340.

8. Information unit -Central Administration for Agricultural Extension 2015. Infounit@caae-eg.com/neem trees.

9. IOOC. 2001. Method of Analysis of the International Olive Oil Council Preparation of the fatty acid methyl esters from olive oil and olive pomace oil CO/T.20/DOC.No.24. 
10. Kates, N. 1972.Technique of lipidology. American. Elsevisr Publishing Co-Inc. New york. Pyka, A. ands liwio, K. (2001). Chromatographic separation of tocopherols. Journal of Chromatography. 935:71-76.

11. Nöll, G. N. 1996. High performance liquid chromatographic analysis of retinal and retinol isomers. Journal of Chromatography. A, 247-259.

12. Perez-Ruiz, T., Martinez-Lozano, C., Garcia, D. and Martin, J. 2007. High performance liquid chromatography- photochemical reduction in aerobic conditions for determination of $\mathrm{K}$ vitamins using fluorescence detection. Journal of Chromatography A, 1141: 67-72.

13. Rukmini, C. 1987. Chemical and nutritional evaluation of neem oil. Food Chemistry, 26: 119-124.

14. SAS Program. 1996. SAS/STAT User's Guide Release 6.12ed. Cary, NC USA: SAS Inst. Inc.

15. Schmutterer, H. 1995. The neem tree. Source of unique matural products for integrated pest management, medicine, industry and other purposes. VCH weinheim, New York, Basel, Cambridge,Tokyo, p.696.

16. Shin-ichiro, K.,Yoshihisa, T., Fakhruddin, A. A. and yoshiki, K. 2014. Triterpenoids from the fruits of Azadirachtaindica (Meliaceae). Fitoterapia,92: 200-205.

17. Susana Nelson 1995. Food analysis fat characterization (Oscar,A. pike), Chapter 14 , second edition.

18. Venugopalan, S. K. and Visweswaran, N. 2013. Neem (Azadirachtaindica) :prehistory to contemporary medicinal uses to humankined. Asian Pac J Trop Biomed., 3(7) : 505-514.

19. Wikipedia. 2014. http: // en. Wikipedia.Org/ wiki/ Neem oil.

20. Wittiy, M., Krings, U. and Berger, R.O. 2013. Single- Run analysis of vitamin D photoproducts in oyster mushroom (pleurotusostreatus) after UV-B treatment. Journal of Food Composition and Analysis, 31: 266-274.

21. Wong, M. L., Timms, R. E. and Cioh, E. M. 1988. Colorimetric determination of total tocopherols in palm oil, olein and stearin. JAOCS,65(2): 258-261. 


\section{الخواص الطبيعية و الكيميائية لزيوت النيم المستخلصة من البذورو الثمرة الكاملة و لحم الثمرة الثهائه ناهد محمد محروس عطا1 - غادة حسين حامد إسماعيل

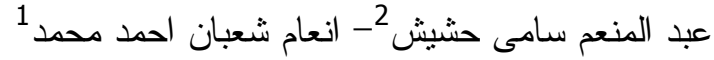

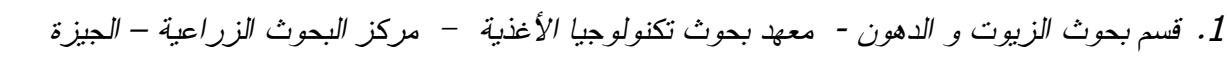

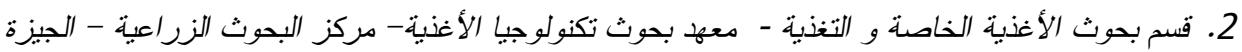

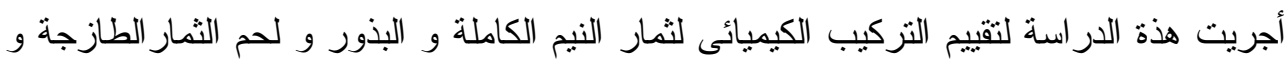

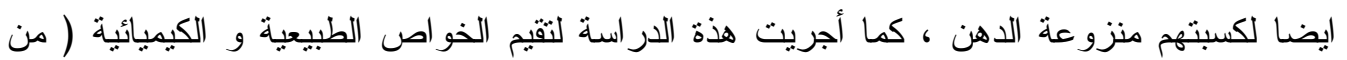

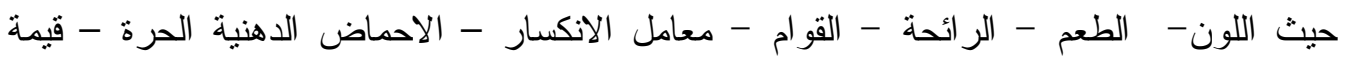

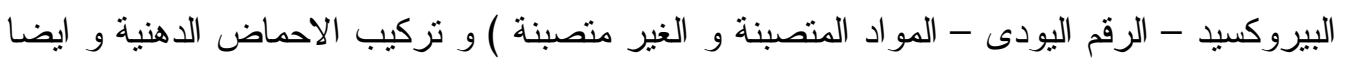
المركبات الفينولية، الفلافونويد و الفيتامينات لزيوت النيم المستخلصة بالمذيب العضوى من الثمار

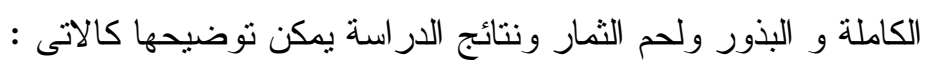

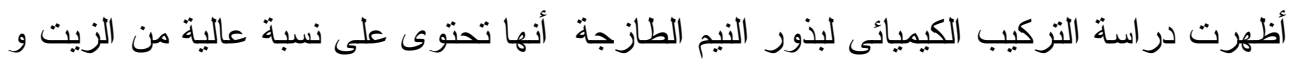

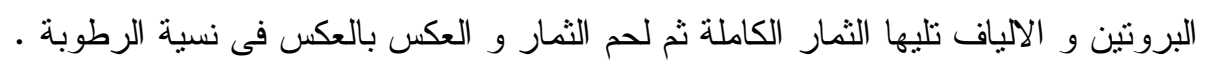

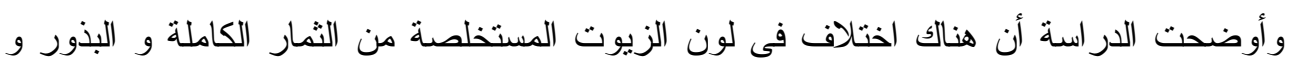
لحم الثمار فكان اللون بنى مخضر و اصفر مخضر و اصفر ذهبى على التو الى اما بالنسبة للطعم

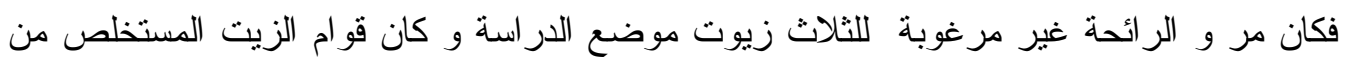
الثمار الكاملة و البذور سائل بينما زيت لحم الثمار كان صلب على على درجة حر ارة الغرفة.

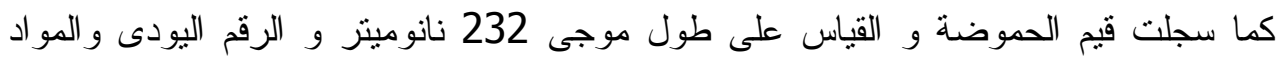

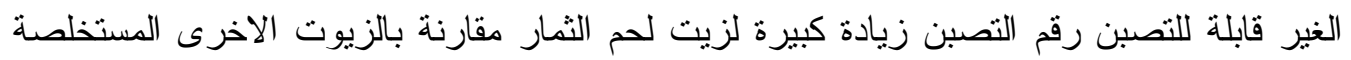

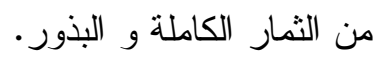

كما أثنارت نتائج تحليل الاحماض الدهنية لهذة الزيوت بواسطة جهاز التحليل الكروماتوجر افى الكى

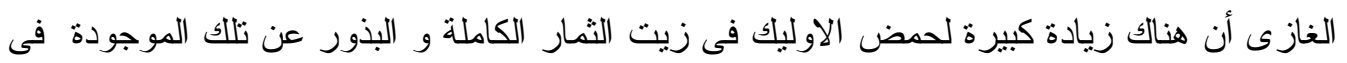

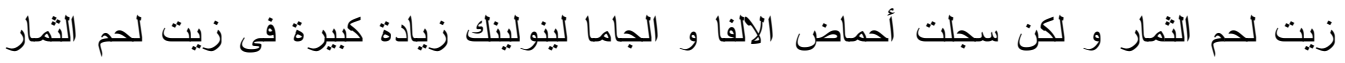
بالمقارنة بالزيت المستخلص من الثمار الكاملة و البذور .

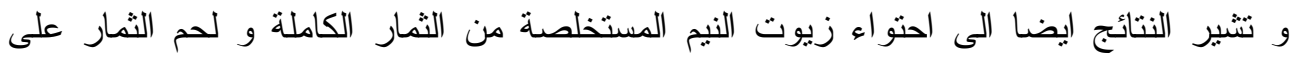

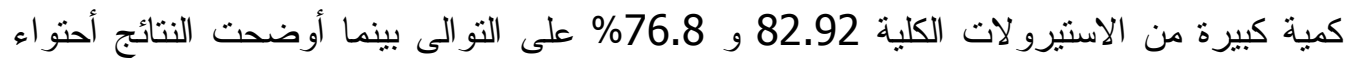

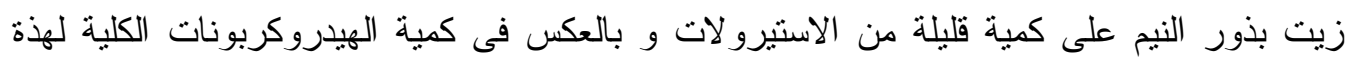

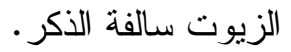

كما أظهر تحليل المركبات الفينولية و الفلافونويد بواسطة جهاز التحليل الكروماتوجر افى السائل

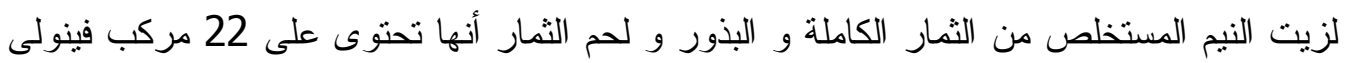
و 11 مركب فلافونويد وعلى أية حال أظهر التحليل أن زيت الثمار و لحمها يحتوى على كمية أكبر من المركبات الفينولية و الفلافونويد مقارنة بزيت البذور ـ ـ كما سجل المركب الفيد الفينولى البيروجالول

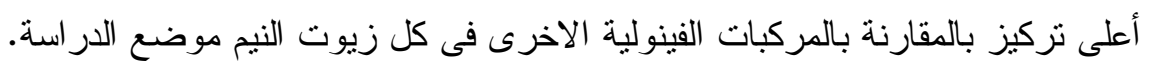

